\section{Early Roots of the Organic Movement: A Plant Nutrition Perspective}

\author{
Ronald F. Korcak
}

Additional index words. humus theory, Justus von Liebig, plant nutrition

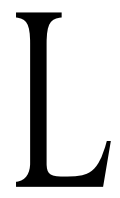

ord Walter Northbourne first used the term "organic farming" in 1940 as a chapter heading in his book Look to the Land (Northbourne, 1940). That same year, coincidentally, was also the 100th anniversary of Justus von Liebig's monograph Organic Chemistry in its Application to Agriculture and Physiology. The fundamental tenet of Liebig's doctrine was the development of the mineral nutrient theory of plant nutrition. About 100 years later, the primary American proponent of organic farming, J.I. Rodale, cited Liebig as the founder of the fertilizer industry (Rodale, 1945) which he probably was, and the N-P-K mentality in agriculture. The basis for these remarks was that "up to that time the humus theory had been the guiding basis for agriculture" (Rodale, 1945). What exactly was the humus theory? How did it evolve? Was it a viable theory? What was the role played by the pivotal player, Liebig? This review follows the evolution of plant nutritional theories from the early use of crop rotations in China, to the development of the humus theory, and finally to the time and work of Liebig and his influence on theories of plant nutrition.

\section{Introduction}

Plant growth has been both a curiosity and a source of much documentation and experimentation since the beginnings of agriculture. The "substance" of plants has been explored and debated since the time of the early Greek philosophers. The current dichotomy over the source of plant nutrients between the organic vs. inorganic fertilizer camps is not new. Democritus of Abdera $(\approx 460$ $360 \mathrm{BC}$ ) proposed what would currently be considered as an atomic philosophy of matter:

Mother earth when fructified by rain gives birth to crops for the nourishment of man

U.S. Department of Agriculture, Agricultural Research Service, Fruit Laboratory, Beltsville, MD 20705, and beast. But that which came from earth must return to earth and that which came from air to air. Death, however, does not destroy matter but only breaks up the union of its elements which are then recombined into other forms. (Browne, 1943)

This atomic, cyclic, and nonconvertible chain ofelements through thesoil-plant-animal system was opposed by Aristotle's (384-322 BC) mutual convertibility of the four elements: earth, water, fire, and air. Since, according to Aristotle, the material constituents of the world were formed from unions of these four elements, plants assimilated minute organic matter particles through their roots which were preformed miniatures (Browne, 1943). This concept of "organic" nutrition of plants, evolving into the humus theory of plant nutrition, held for more than 2000 years, until the time of Justus von Liebig.

The course of experimentation and thinking on the subject of plant nutrition, from the post-Greek philosopher period until the time of Liebig's 1840 monograph, is the concern of this review. Liebig's monograph laid the foundation of a plant mineral nutrient theory that was a precursor for the fertilizer N-P-K mentality of crop fertility. The use and/or abuse of synthetic mineral fertilizers subsequently became the bane of the organic farm movement.

\section{Early investigations}

The beneficial responses observed from using green manures and animal manures and the use of crop rotations on crop growth have directly influenced the development of plant nutrition theories. The earliest record of the benefits of green manures dates back to the Chou dynasty $(\approx 1100 \mathrm{BC})$ in China (Pieters, 1927). Later ( $\approx 500 \mathrm{BC})$, Tsi gave the following advice: "They (green manures) are broadcast in the fifth or sixth month, and plowed under in the seventh or eighth month ... Their fertilizing value is as good as silkworm excrement and well-rotted farm manure" (Pieters, 1927).

King (1911) concluded from travels in the Orient, notably China, that the practice of deliberately adding organic matter to the soil dates back at least 4000 years and summarized his observations as: "This is a remarkable practice in that it is very old, intensive application of an important fundamental principle only recently understood and added to the science of agriculture, namely, the power of organic matter, decaying in contact with soil, to liberate from it plant food."

Early Roman compilations of agricultural practices that enumerated the use of organic manures and crop rotations were accumulated by the prolific agricultural observer Cais Plinius Secundus (AD 23-79) better known as Pliny the Elder (Browne, 1943). He enumerated the advantages and disadvantages of most animal manures and recommended the use of green manures (Browne, 1943). "It is universally agreed by all writers that there is nothing more beneficial than to turn up a crop of lupines, before they have podded, eitherwith the plough or the fork, or else to cut them and bury them them in heaps at the roots of trees and vines."

Though Pliny and subsequent writers over the centuries extolled the benefits of manuring from a scientific viewpoint, little advance was made on the reasons for these benefits. Generally, the Aristotelian concept of the four elements held sway into the Middle Ages. The Middle Ages, generally, represent a quiescent period devoid of any advances in scienceand technology-no less in the understanding of plant mineral nutrition. Some notable exceptions to this void would have profound influences on the development of a theory of plant nutrition near the end of the Middle Ages.

\section{Post-Middle Ages}

Philippus Theophrastus Paracelus (14931541) gained fame as the first scientist to lecture in German, in lieu of the traditional Latin, allowing for understanding and involvement in scienceamong lay persons, and recognition of the importance of experimentation in chemistry (Browne, 1943). More germane to plant nutrition, he initiated a new concept of plant nutrition, which was not aligned to the Aristotelian four elements. He stated:

.. So also every vegetable of the earth must give nutriment to the three things of which they consist. If they fail to do that the prima Condita (first substance) perish and die in their three species. These nutriments are earth and rain, that is the Liquor, each of the three parts of which nourishes its own kind-sulfur for sulfur, mercury for mercury, and salt for salt, for Nature contains these, one with the others. (Browne, 1943)

A modern-day interpretation of this passage indicates that the nourishment of plants requires three principles: organicconstituents (sulfur), water (mercury), and mineral matter (salt). There is even a hint at the "law of the minimum" concept of plant nutrition. Although the "three-principle" theory of Paracelus differs only slightly from that of Aristotle's four elements, it represents, as Browne (1943) points out, a "break with an outworn tradition."

The search for the true "substance" of plants and a continuance of the break with the four elements of Aristotelian theory was furthered by Bernard Palissy (1510-1589). Considered by some to be the founder of agricultural chemistry (Browne, 1943), Palissy relied on observation and experience in making practical theories for manuring: "Manure is carried to the field for the purpose of restoring to the latter a part of what had been removed Proceeding thus you will restore to the soil the same substances that have been removed by previous crops and which following crops will regain to their advantage." 
The idea that the same substances will be reused by other crops would become central to the development of the humus theory of plant nutrition 200 years later. Palissy also helped to overthrow the concept of heat as important in the growth of plants. Through the ages, the heat given off by a pile of composting manure probably drew the attention of many observers. This readily noticeable trait coupled with the fire element of Aristotle was thought to be the "substance" from which plants benefited from manuring. Palissy had observed that the benefits of marl (as a soil amendment) were long term and, therefore, not explicable in terms of heat.

No chronology of the early development of plant nutrition would be complete without mention of Jan Baptista van Helmont (1577-1644) and his infamous potted tree experiment, which lasted 5 years (Browne, 1943). The experiment, in brief, consisted of growing a 5-lb willow tree in a capped, earthen vessel containing $200 \mathrm{lb}$ of oven-dried soil. After 5 years, with the addition of only water, the tree weighed $\approx 169 \mathrm{lb}$ and the redried soil just $2 \mathrm{oz}$ less than $200 \mathrm{lb}$. The conclusion was that the 164-lb gain in tree weight was derived from water. Unfortunately, no mention is ever made if van Helmont weighed the water applied during the experiments 5 years. If he had, his conclusion, obviously, would have been different. Van Helmont had performed prior experiments with combusting charcoal and found $1 \mathrm{lb}$ of ash from $62 \mathrm{lb}$ of charcoal. The other $61 \mathrm{lb}$ consisted of the "spirit of the wood," which he coined "gas" (Browne, 1943). Had he measured the water applied and applied his spirit of the wood concept, plant nutritional theory may have been advanced by $\approx 100$ years.

Eighty years later, the classic water culture experiment of John Woodward (1665-1728) dispelled the concept of water as the sole substance of plants (Russell, 1926). Woodward, in 1699, noted better spearmint growth in water containing garden soil than when grown in rain water, or impure water (from the Thames River).

Although van Helmont believed that the growth substance of plants was water, it was likewise known that salts were an important plant constituent. This idea was generated from the many early decomposition and distillation experiments of plant materials. Two 17th century chemists, Johann Glauber (1604-1668) and Gabriel Plattes (ca. 1600-1655) exemplify the early knowledge of the importance of salts and their relation to both manures and plant nutrition (Browne, 1943). In response to the lack of manures brought about by the havoc of the Thirty Years War, Glauber invented what may be considered the first manure substitute, or chemical fertilizer, to fill the void. He called the material "philosophic dung" or "fattening salt" and noted:

Of this salt, which we may use instead of dung, there is great diversity, for it is prepared of Wood-ashes, of Stones burnt to Lime, and of other bodies putrefied by length of time. But the Chief of all these is Salt-petre, being the salt of Vegetables, Animalsand Minerals putrefied, especially because it is endowed with a certain occult and sweet Fire. (Browne, 1943)

Glauber did not realize that this organically based "fertilizer" added N-P-K as well as lime to soils. Saltpeter (potassium nitrate) was thought to be a constituent of plants, not a nitrate source; therefore, by addition to the soil, one was adding an intrinsic part of the plant and thereby maintaining the "fatness" of the soil (Russell, 1926). The term "fatness" was coined by Plattes as the cropsustaining ingredient of soils (Browne, 1943). He considered both the air and soil as valuable in plant nutrition: "All fruits are compounded of a doublesubstance, the one terrestriall and the other aethereall, and for the most part, the want of the terrestriall part causeth ill successe" (Browne, 1943).

The fatness of the soil, akin to its organic component, could be removed either by crops or carriedaway by erosion. Rudiments of this concept of a soil's fatness can still be found today in the adage "living off the fat of the land."

Coincident with the work of Glauber and Plattes was a change in the English system of agriculture from manorial to closed farms. Not only was individual initiative greater, but newer crops allowed for more farm animals and, thus, more manure. New rotation systems, such as the Norfolk rotation (Porteous, 1960) eliminated the fallow year but included a legume crop for feed or for green manure. Green manuring with legumes became the mainstay of rotation systems in continental Europe as well. By the end of the 17th century, much debate in Germany centered on whether or not the legume crop should be harvested or turned under (Pieters, 1927).

In the late 17th century, John Mayow(16431679) and Nehemiah Grew (1641-1712) recognized the importance of air in plant growth, and in the New World, John Winthrop (1606-1676) promoted the importance of salt and the manufacture of fertilizer saltpeter (Browne, 1943). Grew conceptualized the root as a mouth into which entered a watery nutriment solution from the soil, along with air. The "principles" of plant growth were preformed, carried into the plant, and then filtered among the various plant parts. John Woodward, noted earlier for his classic experiment refuting van Helmont's water-only theory of plant nutrition, continued Grew's argument for preformed entry of nutriment into the plant. He further elaborated that different plants require different "corpuscles" (the preformed substances of plants) and "... that every kind of vegetable requires a peculiar and specifick matter for its formation and nourishment ... . If therefore the soil, wherein any vegetable or seed is planted contains all or most of these ingredients ('corpuscles'), and those in due quantity, 'twill grow and thrive there: otherwise "twill not grow" (Browne, 1943).

According to Woodward, the soil could be regenerated only with a "new Fund of matter" by fallowing, which enabled rain to supply a new stock, or by manuring; particularly with vegetable manures, since they would serve "for the formation of other like bodies" (Browne, 1943). Woodward's concepts of the importance of earth in the nutrition of plants were advanced by his contemporary, Jethro Tull (1674-1740). Although best known for his ideas concerning tillage, Tull believed that fine particles of soil entered the root; therefore, the finer the soil particles, via tillage, the better the growth. "And Earth is surely the Food of all Plants, that with the proper share of the other elements, which each Species of Plant requires, I do not find but that any common Earth will nourish any Plant" (Browne, 1943).

In regards to the use and nutritional value of manures, Tull ascribes their benefit to the enhanced mechanical and physical properties of the soil:

All sorts of Dung and Compost contain some Matter, which, when mixt with the Soil, ferments therein; and by such Ferment dissolves, crumbles, and divides the Earth very much; This is the chief, and almost only Use of Dung . . . This proves, that its (manure) use is not to nourish, but to dissolve, i.e., Divide the Terrestrial Matter, which affords nourishment to the Mouths of vegetable roots. (Browne, 1943)

\section{The phlogiston period}

The doctrine of the phlogiston school of early agricultural chemistry was that all substances that are changed by ignition contain a common combustible matter (Browne, 1943). The most important influence of this doctrine on plant nutrition was the general assumption that plants generated alkalis (Russell, 1961).

Advances of a plant nutrition theory during this period resulted primarily from the work of Francis Home (1719-1813). He not only recognized the importance of pot studies and plant analysis (Russell, 1961) but also added fire and oil to the list of important factors (air, water, earth, and salt) in plant nourishment:

I join, in some measure, with all these; and assert that plants are nourished by these bodies, united with two others, oil and fire in a fixed state. These six principles together, in my opinion, constitute the vegetable nourishment. (Browne, 1943)

Oil was considered one of the "natural principles" that was introduced to earth in rain, and fire was found "in all bodies." Home's work marks one of the cornerstones in plant nutrition theory, i.e., a multitude of factors are considered to explain the nourishment of plants. 
Like Home, Johann Wallerius (1709-1785) considered plant nutrition a multifaceted science. Regarding plant growth in general, Wallerius believed, "Plants derive no growth from any mineral earths Thesubstances that promote plant growth must be (1) identical or analogous with substances preexisting in the plant, or (2) capable of being transmuted and combined into a nature that belongs to plants" (Browne, 1943). Therefore, humus was the "nutritiva" or source of plant food while all other soil constituents were the "instrumentalia" that assisted in making this food available (Russell, 1961).

Other notable discoveries during the phlogiston period would have profound influence on the development of plant nutritional theories. These include the discovery of $\mathrm{O}_{2}$ by Joseph Priestly (1733-1804) and his work on the purification of air by plants and the discovery by Jan Ingen-Housz (1730-1799) that plants give off $\mathrm{CO}_{2}$. Air, or more properly "fixedair," became the important principle of plant nutrition and, as Priestly stated, "the principle is phlogiston" (Browne, 1943).

\section{THE HUMUS THEORY OF PLANT NUTRITION}

The beginning of the 19th century coincided with the chemical revolution in agricultural science. However, remnants remained of those who believed in the Aristotelian four principles, phlogiston adherents, and transmutation power of plants. Before advancing through this period of achievement in agricultural chemistry and plant nutrition to the time of Liebig, it is worth exploring what the humus theory of plant nutrition was and how the preLiebig scientific community accepted or rejected this theory.

The idea that increasing soil organic matter, either by plant residues or animal manures, increased soil fertility and hence crop yields had been realized, as we have seen, for centuries. This readily verifiable role of organic matter, or humus, combined with the later question concerning the source of $\mathrm{C}$ for plant growth, led to the humus theory of plant nutrition. As noted earlier, Wallerius in 1761 was the first to allude to the idea that humus was the food of plants (Kononova, 1961). A half century later, Albrecht Thaer (1752-1828) is credited with formulating the theory of the humus nutrition of plants (Waksman, 1942).

Humus was considered the sole and direct source of plant nutrients. Waksman (1942) summarizes the humus theory, which had gained the support of early chemists, including Theodore de Saussure (1767-1845) and Sir Humphrey Davy (1778-1829):

According to this theory, plants feed upon substances which are similar to them in nature. The organic matter of the soil, or the soil humus, was regarded as the chief nutrient for plants and the major source of soil fertility. The roots of the plants were believed to extract the humus from the soil and to transform it into plant substance, by combining it with water. Plant nutrition was thus considered as similar to animal nutrition, both plants and animals feeding upon complex organic bodies. As regards the function of minerals in plants, some of the protagonists of the humus theory believed that these were not essential for growth; they were believed to act as stimulants rather than as nutrients. Others looked upon minerals as mere accidental plant constituents, or as the skeleton substances of plants similar to the bones of animals.

\section{The Modern Period}

Theodore de Saussure, the eminent Swiss chemist, in his Chemical Researches on Plants (1804), overthrew many of the transmutation and "principle" concepts of his predecessors. As Russell (1961) stated, de Saussure's "conciseand logical arguments" are refreshing compared to the "lengthy and often wearisome works of earlier writers." Among the accomplishments accorded de Saussure are theelucidation of plant respiration; the recognition that soil, not air, was the supplier of $\mathrm{N}$; the realization of the active role of the root as an absorber of water and salts, not as a mere filter; the realization that ash constituents of plants all occur in humus; and debunking the idea that plants generate potash (the salt principle of his predecessors) (Russell, 1961). About 36 years later, Liebig erroneously argued that air was the source of plant $\mathrm{N}$ (ammonia) and that this supply limited growth.

De Saussure, however, was a defender of the humus theory. His general conclusions of plant nutrition included:

That fertile soil contains a mixture of soluble and insoluble organic substances and that the entrance of the former into the plant through the roots is a most important aid for the nourishment which they derive from air and water.

That plants obtain their nitrogen almost wholly by absorption of the soluble organic substances: direct experiment shows that they do not assimilate it to an appreciable extent in the gaseous condition (Browne, 1943)

Contradictory evidence for and against the concept that plants had the power of transmutation to produce the principle of growth, and controversy over the importance of organic vs. inorganic nutrition of plants, reached an interesting stage by 1838. A prize was offered in Germany for the most satisfactory answers to the questions: Do the socalled inorganic elements, which are found in the ashes of plants, occur in these plants when the exterior sources of these elements are eliminated? Are these inorganic elementary constituents so essential that the vegetable organisms have constant need of them for their complete development (Browne, 1943)? The prize was awarded to A.F. Wiegmann (1771-1853) and L. Polstroff for their conclusions from an experiment comparing plant growth in a synthetic soil vs. sand alone. They concluded, in part, "The inorganic constituents of plants can in no respect be regarded as products of their vital activity either as formations from unknown elements or as peculiar derivations of the four elements known to make up organic substances" (Browne, 1943).

In regards to inorganic nutrition and manuring, Wiegmann noted that "...the soil has been so robbed by the previously harvested crop of the inorganic materials which are necessary for plant development that another crop of the same kind (even when the ground is plowed and newly fertilized with an animal manure deficient in the necessary mineral element) is unable to find the requisite amount of plant food that is necessary for its complete development" (Browne, 1943).

Opposition to the humus theorywas to come from manysides. Experimentswith humusextracts led Wiegmann and Polstrof to conclude that humus plays an insignificant role in plant nutrition (Browne, 1943). Carl Sprengel (1787-1859) also ascribed little nutritive value to organic matter:

The conviction should have been reached long ago that humus is not such an important substance as we have been led to believe and that the current doctrine of humus (the humustheory) is exceedingly full of contradictions I have come more and more to the conviction that plants can entirely dispense with it (humus). (Browne, 1943)

Sprengel supported de Saussure's opposition to the old theory of transmutation of mineral elements by plants and suggested that the mineral elements of plants are derived from without. The supply of mineral elements depends on the chemical composition of the soil. Much work by Sprengel involved classifying fertilizing materials (Browne, 1943). He separated organic fertilizers from mineral materials such as lime, clay, and a host of salts. These and other details of Sprengel's writings, such as those on the effects of minimum and maximum factors on the growth of crops, led Browne (1943) to conclude that “...Sprengel should always be remembered as the one who paved the way for Liebig..."

Among the last eminent pre-Liebig scientists was Jean-Baptiste Boussingault (1802-1887). Boussingault's most significant impact on plant nutrition was his initiation of the first series of field experiments (Russell, 1961). Boussingault and his contemporary Gerardus Mulder (1802-1880) were both proponents of the humus theory of plant nutrition. 
In 1840, the Chemical Section of the British Association for the Advancement of Science requested a report on the state of organic chemistry (Bradfield, 1942). The invitee was Justus von Liebig. The opening paragraph of his Organic Chemistry in its Application to Agriculture and Physiology would define organic chemistry, and, according to many, the rest of the text would have dramatic implications on the practice of agriculture and plant nutrition. The opening paragraph states, "The object of organic chemistry is to discover the chemical conditions essential to the life and perfect development of animals and vegetables, and generally to investigate all those processes of organic nature which are due to the operations of chemical laws" (Bradfield, 1942).

\section{Justus von Liebig}

Justus von Liebig (1803-1873) was recognized as one of the most distinguished chemists of his day (Fig. 1). His combined activities as investigator, editor, teacher, and writer were unequaled during his career (Browne, 1942). His theory of the mineral nutrition of plants has dominated the thinking of most students of soils and plant nutrition. Moore (1947) perhaps presents the best condensed interpretation of Liebig's theory: "The soil was a sort of reservoir from which man could take out no more than he put in."

Two important plant nutrition-related controversies were broached by Liebig: thecontroversy concerning the source of $\mathrm{C}$ and that concerning the source of $\mathrm{N}$ in plant nutrition.

The humus theory held that humus was the source of C. Liebig argued, in a typical scathing attack on his contemporaries and predecessors, that prior experiments on humus as the $\mathrm{C}$ supplier "... are considered by them as convincing proofs, whilst they are fitted only to awake pity" (Russell, 1961). Liebig claimed that plants had an inexhaustible supply of carbonic acid in the air. According to Liebig, humus was primarily a source of $\mathrm{CO}$, from decomposition, but the role of this $\mathrm{CO}$, was to aid in the solubility of inorganic soil constituents (Kononova, 1961). An additional benefit of this humus-derived $\mathrm{CO}_{2}$ was the increased absorption by leaves as it diffused from the soil (Waksman, 1938).

Later, however, Liebig does attribute one role of humus as a $\mathrm{C}$ supplier to plants, but in a nonhumustheory form, e.g., humus in an altered state. "Humus does not nourish plants, by being taken up and assimilated in its unaltered state, but by presenting a slow and lasting source of carbonic acid which is absorbed by the roots and is the principle nutriment of young plants at a time when, being destitute of leaves, they are unable to extract food from the atmosphere" (Waksman, 1942).

Liebig seems to waver as to the role of humus as the source of plant $\mathrm{C}$. His opinion that humus per se was not assimilated by plants was "proof" that the humus theory was not valid.

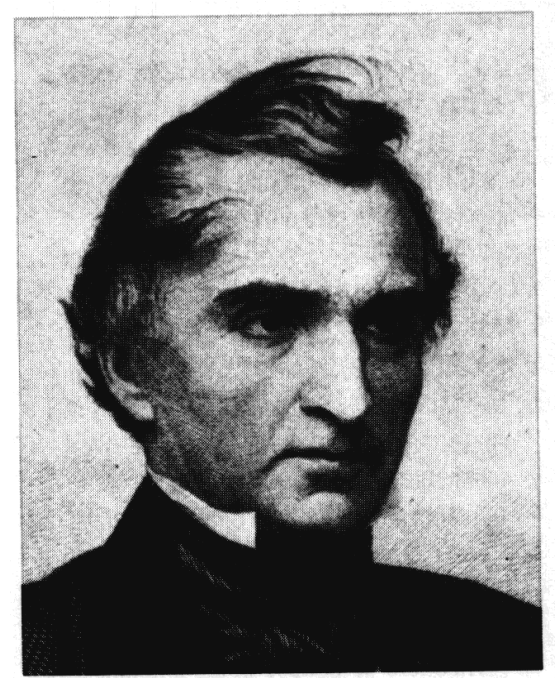

Fig. 1. Justus von Liebig (1803-1873).

Similar vacillations by Liebig can be found on the topic of the source of plant N. Liebig maintained that atmospheric ammonia, not humus-derived $\mathrm{N}$, was the source of plant $\mathrm{N}$. However, Liebig's stance on this important question is of interest. In hisoriginal monograph, Liebig states, "Cultivated plants receive the same quantity of nitrogen from the atmosphere as trees, shrubs, and other wild plants; but this is not sufficient for the purposes of agriculture" (Browne, 1943).

In subsequent editions, the last portion of Liebig's statement was changed to read “... and this is quite sufficient for the purposes of agriculture ...," a change that was to have a profound impact (Browne, 1943). What caused Liebig to alter this most important sentence is not known. Liebig was intrigued by the problem facing the colonists in Virginia, who, after a century of wheat and tobacco production without the addition of manure, were now abandoning their lands. He ascribed this development to the century-long drain on the mineral elements in the soil, not to insufficient $\mathrm{N}$ or a reduction in soil humus. This conclusion was consistent with Liebig's concept of an atmospheric source of plant $\mathrm{N}$.

Liebig did recognize, however, that animal manures were important sources of $\mathrm{N}$ (Bradfield, 1961). He had experimented with cow manure (low in $\mathrm{N}$ ) and human urine (high in $\mathrm{N}$ ) and reported more favorable gluten production from wheat grown from the latter amendment. Three pages later in his monograph, Liebig notes the following, which probably could be found among the pages of many present-day organic magazines: "It should be the care of the agriculturalist so to employ all the substances containing a large proportion of nitrogen, which his farm affords in the form of animal excrements, that they should serve as nutriment to his own plants" (Bradfield, 1942).

Liebig's theories on the atmospheric source of ammonia-nitrogen for plant growth led John Lawes in 1843 to establish the now infamous Broadbalk Field wheat experiment at Rothamsted
(Russell, 1926). These experiments showed the value of phosphates and alkali salts, which Liebig had emphasized, but they also vividly showed Liebig's mistake in relying solely on an atmospheric source of N. The initial studies led Lawes to formulate a "patent manure" consisting of a mixture of superphosphate, phosphate of ammonia, and silicate of potash (Russell, 1926). A similar artificial manure was patented by Liebig (1845) but since it was based on the ash composition of plants, its use was short-lived.

Besides these observationsand opinions on the current controversies of his day, Liebig also noted the relationship of plant ashes to crop requirements and that water extracts of humusyielded little or no residue upon evaporation (Howard, 1940). He espoused the concept that ash analysis would foretell which salt would need to be applied to obtain a full crop. Acceptance of this concept led to the downfall of the humus theory, since the two concepts could not coexist. However, the ash concept often is cited as one of Liebig's false conclusions in relation to the value of organic manures.

\section{Conclusions}

The evolution of plant nutrition theory has been outlined from the fundamental observations of ancient writers, who believed that manures produced better crops, to the time of Justus von Liebig, when visual observations were merged with the chemistry of the day. The mysterious heat given off from the composting of manures and the resulting brownish-black liquor provoked the curiosity of many through the ages. If we ascribe this progression in plant nutrition theory to the "scientific advancement" achieved in all fields, one also realizes that this progression was not independent of the society then in existence. Thus, Glauber's salt, one of the early saltpeter mineral fertilizers, was not only the product of his scientific endeavor but also a reaction to the devastation of the Thirty Years War. Similarly, in Liebig's time, according to Sykes (1949) in England, the establishment of artificial manures was not only due to Liebig's theories but also helped "... by the decline in agricultural technique; by the necessity to reduce agricultural costs; and by the influences, everywhere in evidence, which were compelling the farmer to get more out of the land, to put less into it, and to diminish costs at every turn."

Nor does the progression of a theory necessarily produce a perfect correlation with truth. The abstract notion that plants contained a "force" or "creative power" to transmute substances was finallytoppled by Liebig. However, although Liebig knew of the benefits of manures from a $\mathrm{N}$ standpoint, he opted, erroneously, for a purely atmospheric origin for plant $\mathrm{N}$. The fact that Liebig was a "compiler and summarizer" of the importance of mineral nutrients placed hismineral elementtheory 
on an unsound foundation (Marschner, 1986). However, this became the primary reason for the work of Lawes and many other scientists to follow.

Twenty years after the publication of Liebig's monograph, the science of microbiology began to flourish (Waksman, 1938); after another 20 years, Darwin published his study on the effects of earthworms (Darwin, 1976). Studies in soils and plant nutrition would no longer be considered in the context of an abiotic system. The dynamic nature of soil and the role of humus as a microbial media were not and could not be envisioned in Liebig's day.

\section{Epilogue}

Given the state of knowledge during Liebig's career, one would be hard-pressed to accept his summations as the harbinger of doom for the world's production of food and fiber via the route of the chemical fertilizer industry. Current plant nutrition theory recognizes the ionic uptake of nutrients from the soil through the root. Selectivity exists and varies between plant species as to which elements are taken up and to what extent. However, this occurs independent of the source of the nutrients, either synthetic or organic fertilizers.

What then is the controversy between synthetic chemical fertilizer and organic fertilizer users? Ultimately, if the plant uses $\mathrm{N}$ from dried blood or ammonium nitrate in a similar fashion, why should one be a better approach? The arguments, pro or con, run the gamut from a concept of a "living earth" to economics and human health. Many of the contentions between the organic and chemical fertilizer proponents are not germane to plant nutrition per se. However, there are several points that have direct bearing on plant nutrition. Included among these are nutrient concentration and release rate, a dead vs. a living system, and economics. Numerouscitations on the abuses and the benefits (albeit short term) of chemical fertilizers can be made. Research on slow-release fertilizers, fertilizer placement, split applications, and the like are examples of a desire to maximize nutrient uptake with a concurrent increase in yield. However, concepts such as using fertilizer as "cheap crop insurance" on high-value crops are abusive.

According to Balfour (1947) Liebig's theory of mineral plant foods was a "rather naive theory" since it considered only mineral salts. As noted earlier, a concept of a dynamic, living soil was beyond the scope of Liebig or any of his contemporaries. It is, perhaps, more unfortunate that, even today, this view is still held by many.

The driving force behind the acceptance or rejection of the mode of providing nutrients to the plant was, as with the advent of Glauber's salt, and is economics. Turning the economic wheel in either direction may not be the role of those wearing the cap of plant nutritionist, but we can hope future roads may be paved that lead to an enhanced appreciation of the dynamics underlying the nutrition of plants.

\section{Literature Cited}

Balfour, E.B. 1927. The living soil. Faber \& Faber, London

Bradfield, R. 1942. Liebig and the chemistry of the soil, p. 46-55. In: F.R. Moulton (ed.). Liebig and after Liebig. Amer. Assn. Adv. Sci. Special Publ. 16, Washington, D.C.

Browne, C.A. 1942. Justus von Liebig-Man and teacher, p. 1-9. In: F.R. Moulton (ed.). Liebig and after Liebig. Amer. Assn. Adv. Sci. Special Publ: 16, Washington, DC.

Browne, C.A. 1943. A source book of agricultural chemistry. Chronica Botanica 8(1):1-290.

Darwin, C. 1976. Darwin on earthworms. Bookworm Publ. Co., Ontario.

Howard, A. 1940. An agricultural testament. Oxford Univ. Press, London.

King, F.H. 1971. Farmers of forty centuries. Harcourt, Brace Publ., New York.

Kononova, M.M. 1961. Soil organic matter. Its nature, its role in soil formation and in soil fertility. Pergamon Press, New York

Liebig, J. 1845. An address to the agriculturalists of Great Britain explaining the principles and use of his artificial manures. Thomas Baines, Liverpool, England.

Liebig, J. 1964. Organic chemistry in its application to agriculture and physiology. Johnson Reprint Corp., New York. (Facsimile Cambridge ed., 1842.)

Marschner, H. 1986. Mineral nutrition of higher plants. Academic, New York.

Moore, E.J. 1947. Men who went before, p. 1-16. In: Science in farming. The yearbook of agriculture 194347. U.S. Govt. Printing Office, Washington, DC.

Northbourne, W.E. 1940. Look to the land. Dent, London.

Pieters, A.J. 1927. Green manuring. Wiley, New York.

Porteous, C. 1960. Pioneers of fertility. Clareville Press, London.

Rodale, J.I. 1945. Pay dirt. Farming \& gardening with composts. Devin-Adair Co., New York.

Russell, E.J. 1926. Plant nutrition and crop production. Univ. California Press, Berkeley.

Russell, E.W. 1967. Soil conditions and plant growth. Wiley, New York.

Sykes, F. 1949. Humus and the farmer. Rodale Press, Emmaus, $\mathrm{Pa}$.

Waksman, S.A. 1938. Humus. Origin, chemical composition, and importance in nature. 2nd ed. Williams \& Williams Co., Baltimore.

Waksman, S.A. 1942. Liebig-The humus theory and the role of humus in plant nutrition, p. 56-63. In: F.R. Moulton (ed.). Liebig and after Liebig. Amer. Assn. Adv. Sci. Special Publ. 16, Washington, DC. 